\title{
Pengaruh Waktu Pra-etching Dan Ketebalan Film Pada Residual Stress Dari Thin Film Aluminium Nitrida Pada Sensor Magnetoelektrik
}

\author{
Hafid Suharyadi \\ Sekolah Tinggi Energi dan Mineral Akamigas, Cepu
}

\begin{abstract}
ABSTRAK
Komposit magnetoelektrik (ME) terdiri dari lapisan piezoelektrik dan lapisan magnetoelektrik yang disusun secara bergantian. Masalah yang paling sering ditemukan pada hasil deposisi thin film aluminium nitrida (AlN) sebagai lapisan piezoelektrik adalah residual stress. Riset ini bertujuan untuk mengoptimalkan parameter deposisi AlN dalam menghasilkan film AlN dengan residual stress yang mendekati nol tanpa mengorbankan sifat mikrostruktural dan respon piezoelektrik.

Pengaruh waktu pra-etching dan ketebalan film AlN pada residual stress, mikrostruktural, dan respon piezoelektrik telah dipelajari, masing-masing melalui dengan stylus profilometer, difraktometri sinar-X, dan metode 4-point bending. Urutan lapisan film yang dideposisikan pada substrat $\mathrm{Si} / \mathrm{SiO} 2$ adalah $\mathrm{Ta} / \mathrm{Pt} / \mathrm{AlN}$. Metode pulsed DC reactive sputter telah dilakukan untuk mendeposisikan film AlN.

Pengaruh waktu pra-etching pada residual stress AlN tidak menunjukkan perubahan yang signifikan. Nilai residual stress dari film AlN semakin rendah dengan meningkatkan ketebalan film akibat dari peningkatan arah tumbuh preferensial dari kristal AlN. FWHM dari puncak AlN (0002) hampir konstan dalam rentang waktu pra-etching. Dengan meningkatnya ketebalan film, penurunan FWHM dikaitkan dengan pertumbuhan kristal berbentuk kolom yang lebih baik. Hal ini juga menghasilkan magnitudo dari nilai $e 31, f$ yang lebih tinggi.
\end{abstract}

Kata kunci: aluminium nitrida, waktu pra-etching, ketebalan thin film, residual stress, koefisien piezoelektrik transversal.

\section{ABSTRACT}

Magnetoelectric composite (ME) consists of a piezoelectric layer and a magnetoelectric layer which is arranged alternately. The problem mostly found in thin film deposition of aluminum nitride (AlN) as a piezoelectric layer is residual stress. This research aims to optimize AlN deposition parameters in producing AlN films with near zero residual stress without sacrificing microstructural properties and piezoelectric responses.

The effects of pre-etching time and AlN film thickness on residual stress, microstructure, and piezoelectric response have been studied, via stylus profilometer, X-ray diffractometry, and 4-point bending method. The sequence of film layers deposited on the Si/SiO2 substrate is Ta/Pt/AlN. The pulsed DC reactive sputter method has been done to deposition of AlN film.

The influences of pre-etching time on AlN residual stress are not significant. The residual stress of AlN film are lowered by increasing AlN film thickness due to the increase in the preferential growth of AlN crystal. FWHM of AlN (0002) peaks are nearly constant in the pre-etching period. With increasing film thickness, a decrease of FWHM is associated with better columnar growth. This also leads to higher e31, $f$ magnitude.

Keywords: aluminum nitride, pre-etching time, film thickness, residual stress, transverse piezoelectric coefficient.

Email: hafid.suharyadi@esdm.go.id 


\section{PENDAHULUAN}

Film piezoelektrik aluminium nitrida (AlN) saat ini digunakan sebagai lapisan penyusun dalam komposit magnetoelektrik (ME). Karena lapisan piezoelektrik digabungkan secara mekanis dengan lapisan magnetostriktif, hubungan mekanik masing-masing penyusun menjadi penting. Residual stress yang berasal dari proses deposisi film dapat menjadi faktor utama penyebab kegagalan sebuah film. Residual stress yang tinggi dapat menyebabkan kerusakan pada sensor yang dibangun. Oleh karena itu, optimasi residual stress dari film hasil deposisi diperlukan untuk menghasilkan film yang bebas dari residual stress tanpa merusak sifat piezoelektrik dari AlN.

Riset ini bertujuan untuk mengoptimalkan proses deposisi AlN. Luaran yang diharapkan adalah residual stress film AlN yang mendekati nol. Untuk melakukannya, parameter sputtering, seperti waktu pra-etching dan ketebalan film AlN, divariasikan. Perubahan pada sifat film AlN hasil deposisi, yaitu residual stress, mikrostruktural, dan respons piezoelektrik, akan dipelajari.

Teori dasar tentang sifat piezoelektrik, metode deposisi physical vapor deposition (PVD), pertumbuhan film, stress pada thin film, dan difraktometri x-ray akan disajikan. Tahap-tahap eksperimental akan dibahas secara rinci, yaitu persiapan sampel, fabrikasi film dengan menggunakan pulsed $D C$ reactive sputter, dan karakterisasi thin film yang meliputi pengukuran residual stress, XRD, dan metode 4-point bending. Hasil residual stress film AlN akan dianalisis. Hasil pemindaian $\theta-2 \theta$ dan $\omega$ disajikan disajikan untuk menggambarkan kristalinitas film AlN hasil deposisi. Koefisien piezoelektrik transversal efektif e31,f yang terukur juga disajikan.

\section{TINJAUAN PUSTAKA}

Fabrikasi thin film AlN menggunakan PVD menunjukkan adanya pengaruh pada sifat bahan piezoelektrik. Pemahaman dalam fenomena piezoelektrik, sifat material, proses sputtering, dan pengaruh parameter sputtering pada residual stress, mikrostruktural kristal, dan respon piezoelektrik sangat diperlukan.

\section{A. Sifat Piezoelektrik}

Sifat piezoelektrik adalah kemampuan bahan kristal tertentu untuk menghasilkan muatan listrik pada permukaan kristal setelah mengalami mechanical stress atau strain. Muatan listrik per satuan luas, atau disebut Polarisasi P [C/m2], adalah proporsional dengan stress yang diterapkan dan akan hilang ketika stress dihilangkan, seperti yang terlihat di Persamaan 1 (Uchino 2010).

$$
\mathbf{P}=\mathbf{d} \boldsymbol{\sigma}
$$

dimana $d[\mathrm{~m} / \mathrm{V}]$ adalah koefisien piezoelektrik dan $\sigma[\mathrm{N} / \mathrm{m} 2]$. Efek ini disebut juga efek piezoelektrik langsung (lihat Gambar 1). Bahan piezoelektrik juga dapat memiliki efek piezoelektrik invers dimana bahan mengalami deformasi mekanis yang proporsional ke medan listrik yang diterapkan (Uchino 2010).
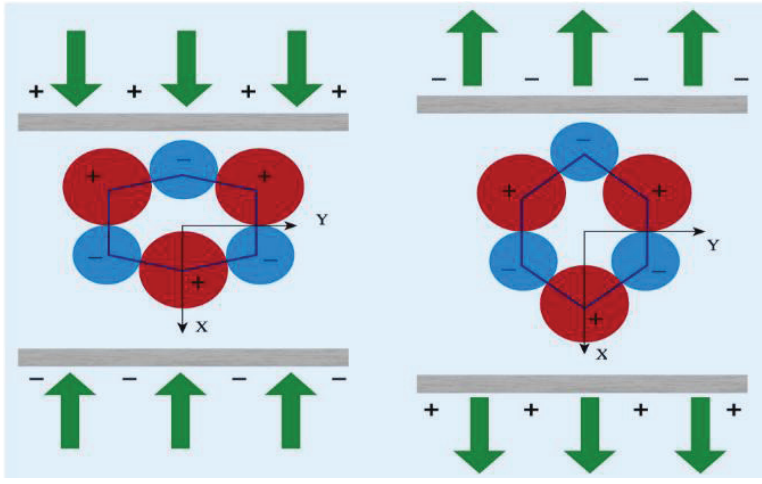

Gambar 1. Compressive stress menginduksi polarisasi dalam arah $-\mathrm{z}$, sedangkan tensile stress menginduksi polarisasi dalam arah $+\mathrm{z}$.

\section{B. Aluminium Nitrida}

AlN memiliki struktur hexagonal wurtzite, seperti yang ditunjukkan pada Gambar 2 (Jahns et al. 2014). Dalam struktur ini, satu atom Al dikelilingi oleh empat atom $\mathrm{N}$ yang membentuk tetrahedron terdistorsi (distorted tetrahedron) dan juga empat atom $\mathrm{Al}$ yang berdekatan terikat pada atom $\mathrm{N}$ yang membentuk tetrahedron terdistorsi yang ekuivalen (Gould and BorchardtOtt 2011). Parameter wurtzite lattice meliputi: a adalah parameter basal plane lattice yang sama dengan panjang tepi hexagonal basal plane dan $\mathrm{c}$ adalah parameter axial lattice yang sama dengan tinggi dari satu sel unit heksagonal. $c / a$ adalah 
rasio parameter lattice $c$ terhadap a (Kittel 2004).
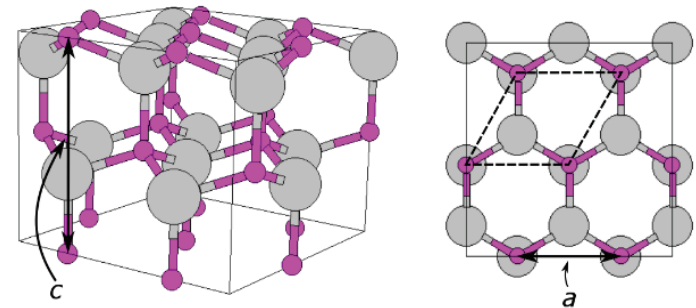

Al atom $\mathrm{N}$ atom lattice parameters: $a=3.11 \AA, c=4.98 \AA, c / a=1.60$

Gambar 2. Struktur kristal wurtzite dari AlN. Gambar kiri adalah perspektif 3 dimensi dengan sumbu-c vertikal; lapisan $\mathrm{Al}$ (abu-abu) dan $\mathrm{N}$ (ungu) yang bertumpuk dapat dilihat. Gambar kanan melihat ke bawah sumbu-c pada basal plane.

Polarisasi pada AlN diinduksi sepanjang sumbu-c. Hal ini berasal dari elektronegativitas tinggi dari anion $\mathrm{N}$ dan elektronegativitas rendah dari kation $\mathrm{Al}$, di samping tidak adanya pusat simetri pada sumbu-c. Atom $\mathrm{Al}$ dan $\mathrm{N}$ yang membentuk ikatan kovalen yang mendistribusikan jumlah elektron tidak sama dimana mayoritas elektron lebih tertarik ke atom N. Pemisahan muatan dalam lapisan hexagonal closed packed yang berisi anion dan kation menginduksi momen dipol di sepanjang sumbu-c pada sel unit (Hummel 2012).

Untuk memiliki polarisasi tertinggi, thin film AlN harus tumbuh dengan orientasi sumbu-c, yaitu dengan arah (0002) tegak lurus terhadap bidang substrat. Tingkat orientasi preferensial akan berkurang dengan penyebaran arah kolom pertumbuhan AlN yang juga merugikan sifat-sifat piezoelektrik. Selain itu, daerah dalam thin film AlN yang memiliki orientasi pertumbuhan yang berbeda dengan arah sumbu polar, sifat piezoelektrik akan berkurang (Eason 2007).

\section{Physical Vapor Deposition}

Physical Vapor Deposition (PVD) adalah proses deposisi thin film di mana atom atau molekul dikeluarkan dari target padat dan dibawa melalui lingkungan vakum tinggi (plasma) ke substrat di mana atom atau molekul tersebut berkumpul menjadi benda padat. Ada beberapa metode PVD, salah satunya adalah sputtering. Dalam sputtering, atom dari material target dikeluarkan karena pemboman partikel yang berenergi tinggi. Atom yang dikeluarkan kemudian diendapkan pada substrat silikon dan diikuti dengan proses nukleasi film pada permukaan substrat (Ohring 2001)

\section{Pertumbuhan Film AlN}

Mikrostruktur film hasil deposisi dipengaruhi oleh parameter deposisi selama pertumbuhan film. Model zona struktur ditunjukkan pada Gambar 3 untuk menggambarkan pengaruh proses fisik terhadap mikrostruktur thin film. Tergantung pada rasio suhu substrat Ts terhadap suhu leleh TM, 3 zona utama ditambah 1 zona transisi dapat dibedakan (Ohring 2001).

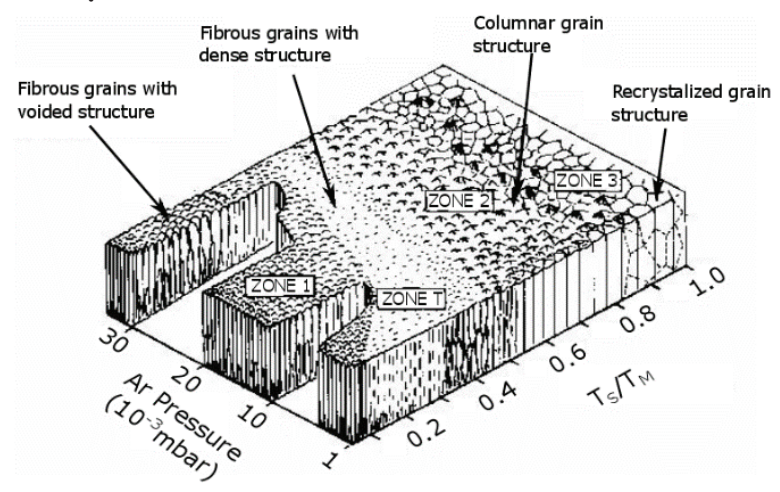

Gambar 3. Representasi skematis model zona struktur yang diperkenalkan oleh Thornton.

Pada riset ini, pertumbuhan film pada zona 2 yang lebih disukai dengan pertumbuhan struktur yang membentuk kolom (columnar structure growth). Difusi atom pada permukaan mendominasi dan jarak antara batas butirnya menjadi semakin rapat.

Mekanisme pertumbuhan thin film AlN dengan deposisi reactive sputtering ditunjukkan pada Gambar 4. (Fase 1) Molekul AlN yang terbentuk pada plasma mengalami kondensasi pada area substrat dan membentuk nucleation sites. (Fase 2) Dengan semakin banyaknya molekul yang terkondensasi, nucleation sites tumbuh menjadi islands AlN (tiga dimensi) yang terpisah. (Fase 3) Islands terus tumbuh dan melebur dengan islands terdekat, menyebabkan islands untuk membentuk grain boundaries dan bergabung satu sama lain untuk membentuk sebuah island tunggal. 
Karena masing-masing island memiliki orientasi kristal yang independen, film yang digabungkan bukan merupakan film dengan orientasi kristal tunggal tetapi kumpulan kristal atau grains yang masing-masing memiliki orientasi kristal masing-masing. (Fase 4) Pertumbuhan film ditentukan oleh laju pertumbuhan normal crystal faces dari kristal. Kristal AlN dengan orientasi (0002) memiliki laju pertumbuhan tertinggi sehingga ketika deposisi berlanjut, kristal ini dapat mengejar pertumbuhan kristal lain dengan bidang orientasi berbeda yang memiliki laju pertumbuhan yang lebih lambat dan kemudian mengkonsumsinya (Eason 2007; Martinez Guerrero and Vargas-garcia 2000).

(a) Fase 1

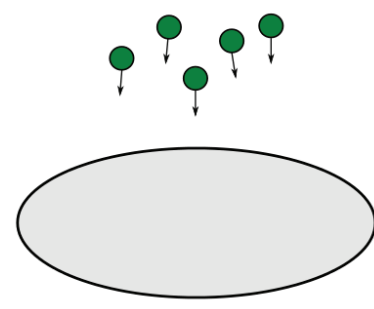

(c) Fase 3

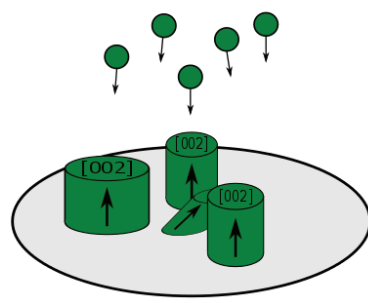

(d)

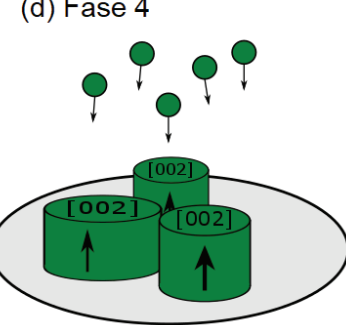

Gambar 4. Mekanisme pertumbuhan film dalam empat tahap selama deposisi dengan metode sputtering pada thin film AlN.

\section{E. Stress pada Thin Film}

Stress ( $\mathrm{Pa}$ atau N/m2) didefinisikan sebagai gaya yang diterapkan per satuan luas penampang. Thin film, tanpa kehadiran gaya eksternal, dapat mengalami stress dan menunjukkan internal stress atau residual stress. Residual stress dari thin film $\sigma_{f}$ adalah kombinasi dari thermal stress $\sigma_{T}$ dan intrinsic stress $\sigma_{i}$, seperti yang diberikan oleh Persamaan 2 (Ohring 2001). Thermal stress muncul dari ketidaksesuaian koefisien ekspansi termal antara substrat dan film. Karena perubahan suhu, substrat dan film mengembang atau menyusut dengan laju yang berbeda. Karena film terikat kuat pada substrat dan regangan komposit dipertahankan, respon mekanik kedua lapisan akan dibatasi sehingga menghasilkan thermal stress (Madou 2018).

$$
\sigma_{-} f=\sigma_{-} T+\sigma_{-} i
$$

Intrinsic stress terjadi selama deposisi thin film, baik yang bersifat compressive atau tensile. Intrinsic stress bersifat tensile ketika film cenderung berkontraksi relatif terhadap substrat, sedangkan compressive stress diperoleh saat film cenderung meregang relatif terhadap substrat (lihat Gambar 5). Intrinsic stress dapat bersumber dari beberapa faktor, antara lain interaksi antar grains, atomic peening, microvoids, gas yang terjebak, dan lattice mismatch antara substrat dan film (Madou 2018).

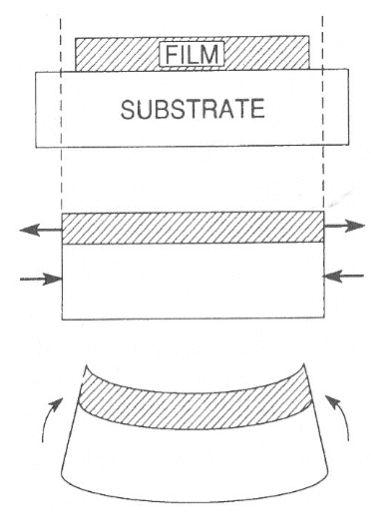

a) Film yang mengalami residual tensile stress
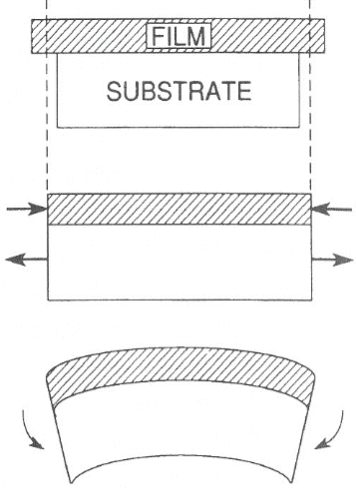

b) Film yang mengalami residual compressive stress
Gambar 5. Urutan kejadian yang mengarah pada (a) residual tensile stress dan (b) residual compressive stress pada film.

\section{E.1.Epitaxial Growth}

Kualitas film yang tumbuh secara epitaxial sangat dipengaruhi oleh substrat. Ketika film yang dideposisi memiliki bahan yang berbeda dengan substrat, prosesnya disebut pertumbuhan heteroepitaxial. Karena atom pada lapisan awal film yang tumbuh dan terikat pada atom substrat, atom-atom ini dipaksa untuk mengikuti lattice dari substrat. Film meregang dengan mendistorsi sel unit untuk mengakomodasi lattice mismatch. 
Misfit strain $\varepsilon f$ didefinisikan pada Persamaan 3, dengan $a_{f}$ adalah lattice constant untuk film dan $a_{s}$ adalah lattice constant untuk substrat (Smith 1995).

$$
\varepsilon_{f}=\mid \begin{gathered}
\left|a_{s}-a_{f}\right| \\
a_{f}
\end{gathered}
$$

Strain energy yang disimpan di dalam film yang meregang sebanding dengan volume dan ketebalan film. Di bawah ketebalan kritis (critical thickness), ketebalan di mana dislocation sangat mudah terbentuk, misfit dislocation tidak stabil dan tidak akan terbentuk. Dalam hal ini, misfit diakomodasi oleh elastic strain. Ketika ketebalan film melebihi ketebalan kritis, strain energy cukup tinggi sehingga misfit dislocation cenderung terbentuk pada antarmuka film-substrat untuk mengurangi sebagian strain energy. Dengan bertambahnya ketebalan film, misfit secara penuh diakomodasi oleh dislocation dan tidak ada elastic strain yang dihasilkan. Tergantung pada lattice constant dari film dan substrat, compressive stress $\left(a_{f}>a_{s}\right)$ atau tensile stress $\left(a_{f}<a_{s}\right)$ dapat dihasilkan (Smith 1995).

Martin (Martin et al. 2004) menunjukkan bahwa compressive stress yang besar pada AlN dengan ketebalan rendah dihasilkan dari lattice mismatch yang besar antara film AlN dan seed layer Pt. Lattice constant pada AlN adalah $12 \%$ lebih besar dari jarak Pt-Pt pada bidang (111). Mismatch ini dikompensasi oleh dislocation dalam $100 \mathrm{~nm}$ pertama dari ketebalan film (Dubois and Muralt 2001).

\section{E.2.Peleburan Grain Boundaries}

Pada tahap awal pertumbuhan, film terdiri dari kristal-kristal kecil di Z1. Sejumlah kristal yang terbentuk pada tahap awal melekat kuat pada substrat dan pada pertumbuhan selanjutnya. Internal elastic strain pada kristal cenderung mengalami relaksasi karena jari-jari grains menjadi lebih besar dan internal stress menjadi lebih kecil. Namun relaksasi dicegah karena film diikat secara kuat oleh substrat. Dalam keadaan ini, compressive stress dihasilkan (Ohring 2001).

Ketika film bergerak ke arah struktur ZT atau Z2 yang lebih padat, jarak antara kristal berkurang dan menjadi menguntungkan bagi kristal untuk saling berinteraksi dan mengurangi energi permukaan. Di beberapa titik, interaksi di antara kristal cukup kuat untuk menutup celah dengan deformasi elastis dari islands dan untuk membentuk grain boundaries. Elastic strain energy yang dihasilkan sebanding dengan tensile stress yang dihasilkan (Ohring 2001).

Ketika sejumlah adatom digunakan dalam grain boundaries, compressive stress dihasilkan. Pada Ts/TM yang lebih tinggi dalam Z3, yield lebih mudah terjadi dan merelaksasi sebagian tensile stress dari mikrostruktur (Ohring 2001).

\section{E.3. Mekanisme Lain}

Penjelasan dari mekanisme lain yang berkontribusi pada residual stress dari thin film dijelaskan, sebagai berikut:

1. Atomic peening $\sigma_{i}<0$ : Tumbukan ion dan atom netral pada permukaan film dapat memadatkan film sehingga menghasilkan compressive stress. Bombardir dari ion-ion energetik menghantam atom-atom permukaan. Beberapa dari mereka masuk ke voids dan interstitial sites dalam lattice pada wilayah permukaan film yang menghasilkan densifikasi yang tinggi dan morfologi film yang padat. Pembentukan defects, seperti voids dan dislocations, juga dihasilkan oleh bombardir ion dengan meningkatkan energi ion yang diarahkan ke substrat (Carter 1994).

2. Vacancy annihilation: Beberapa defects dapat dihasilkan selama pertumbuhan film dan difusi adatom pada permukaan film terlalu rendah untuk mengisi posisi yang kosong. Namun kontribusi ini sangat jarang terjadi pada deposisi dengan suhu rendah (Madou 2018).

3. Atom dan gas yang tidak diinginkan masuk ke dalam film yang tumbuh dan mengotori permukaan substrat sebelum deposisi film juga dapat berkontribusi pada intrinsic stress (Madou 2018). 


\section{E.4. Perhitungan Stress}

Film yang menderita residual stress hanya dapat meregang atau berkontraksi dengan menekuk (bending) dan deformasi (deforming) substrat dalam arah vertikal dan tidak ada stress yang diinduksi karena komposit diasumsikan bebas bergerak dalam arah vertikal. Kondisi ini memungkinkan seseorang untuk menerapkan disk method dimana stress film dihitung dengan mengukur jari-jari kelengkungan substrat sebelum $\left(R_{\text {pre }}[\mathrm{m}]\right)$ dan setelah $\left(R_{\text {post }}[\mathrm{m}]\right)$ deposisi film (lihat Persamaan 4) (Dubois and Muralt 2001).

$$
\sigma_{f}=\frac{Y_{s}}{6\left(1-v_{s}\right)} \frac{T^{2}}{t}\left[\frac{1}{R_{\text {post }}}-\frac{1}{R_{\text {pre }}}\right]
$$

dimana $Y_{s}[\mathrm{GPa}]$ adalah Modulus Young dari substrat, $v_{s}$ adalah Poisson's ratio dari substrat, $T[\mathrm{~m}]$ dan $\mathrm{t}[\mathrm{m}]$ masing-masing adalah ketebalan dari substrat dan film. Beberapa asumsi dilakukan, seperti substrat disk tipis dan memiliki sifat elastis isotropik transversal terhadap film normal, tebal film yang dideposisi jauh lebih tipis daripada tebal substrat, dan film terdeposisi seragam di atas substrat (Madou 2018).

Defleksi balok sebelum dan sesudah deposisi film dapat dianggap menyerupai kurvatur dari bola dan sebagai fungsi kontinu $(y=f(x))$ sepanjang bagian kurvatur yang diukur (l). Pengukuran defleksi dilakukan dengan menggunakan metode mekanis (stylus scan). Kelengkungan kurvatur tidak tergantung pada bentuk atau ukuran substrat karena panjang dan lebar film jauh lebih kecil dari jari-jari kelengkungannya. Jari-jari kelengkungan balok dihitung dengan derivasi pertama dan derivasi kedua, seperti yang ditunjukkan dalam Persamaan 5 (Smith 1995).

$$
R(x)=\frac{\left[1+\left(\frac{d y}{d x}\right)^{2}\right]^{3 / 2}}{\frac{d^{2} y}{d x^{2}}}
$$

\section{F. X-ray Diffractometry}

$X$-ray Diffractometry (XRD) adalah cara untuk menentukan mikrostruktur kristal dari thin film hasil deposisi serta orientasi preferensial dari polikristal dan tekstur kristal. Difraksi sinar-x dalam padatan kristal didasarkan pada hukum Bragg (lihat Persamaan 6) (Kittel 2004). Reaksi Bragg terjadi ketika sudut datang sinar-x sama dengan sudut sinar-x yang dipantulkan. Radiasi sinar-x yang dipantulkan dari dua bidang paralel yang berurutan dapat berinteraksi secara konstruktif dan menghasilkan intensitas maksimum pada detektor. Interaksi yang konstruktif terjadi ketika perbedaan jalur antara sinar-x yang berinteraksi $(2 d \sin \theta)$ sama dengan kelipatan bilangan bulat dari panjang gelombang sinar- $\mathrm{x}, \lambda[\mathrm{nm}]$.

\section{$2 d \sin \theta=n \lambda$}

dimana $d[\mathrm{~nm}]$ adalah jarak interplanar antara bidang atom, $\left[{ }^{\circ}\right]$ adalah sudut sinar datang, dan $\mathrm{n}$ adalah urutan pantulan sinar-x terkait dengan perbedaan jalur, dalam hal jumlah panjang gelombang, antara bidang atom yang berdekatan.

\section{F.1. X-ray Diffractometer}

Pengaturan pengukuran XRD secara sederhana ditunjukkan pada Gambar 6. Tiga komponen dari pengaturan pengukuran XRD adalah sumber sinar-X, sampel, dan detektor sinar-X. Sampel terletak di pusat difractometer atau lingkaran goniometer. Sumber sinar-x dan detektor diatur pada keliling lingkaran. Jari-jari lingkaran diatur tetap. Goniometer itu sendiri menyediakan dudukan sampel dimana tempat sampel dipasang (Sardela 2014).

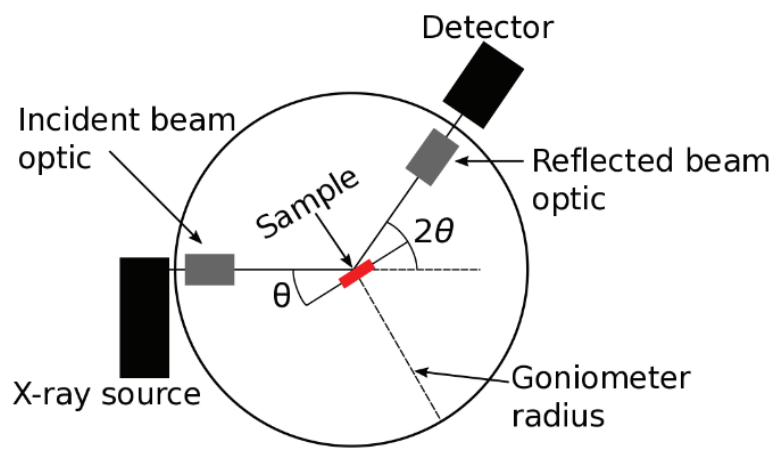

Gambar 1. Skematik dari sistem pengukuran XRD ( $\theta$ $2 \theta$ scanning).

Gambar 6. Skematik dari sistem pengukuran XRD $(\theta-$ $2 \theta$ scanning). 
$\theta-2 \theta$ scanning adalah salah satu konfigurasi geometri dalam mengukur intensitas sinar- $\mathrm{x}$ yang dipantulkan dari sampel untuk menyelidiki orientasi struktur kristal yang ada dalam sebuah bahan (Ohring 2001). Selain itu, w scanning (lihat Gambar 7) dilakukan dengan mengatur sudut $\theta$ dan $2 \theta$ pada puncak Bragg dan memutar sampel sepanjang sumbu $\omega$. $\omega$ scanning sangat sensitif terhadap adanya cacat dan orientasi preferensial.

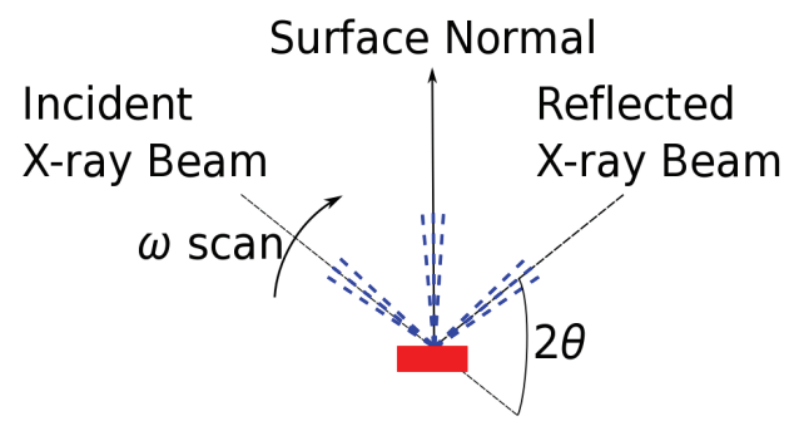

Gambar 7. Skematik dari sistem pengukuran XRD ( $\omega$ scanning).

\section{METODE PENELITIAN}

Gambaran umum tentang parameter proses sputtering disampaikan pada bagian ini. Studi ini fokus pada pengaruh waktu pra-etching dan ketebalan film AlN pada sifat film AlN hasil deposisi, seperti residual stress, FWHM dan $e_{31, f}$ Lebih lanjut, metode investigasi seperti pengukuran stress, pengukuran XRD, dan metode 4-point bending dijelaskan.

\section{A. Penyiapan Substrat}

Substrat silikon 4 inci dan 6 inci (Tabel 1) dipotong menjadi sampel dengan berbagai dimensi, misalnya poligon dengan diameter $32 \mathrm{~mm}$, balok kantilever $2 \mathrm{~mm} \times 10 \mathrm{~mm}$, chip $25 \mathrm{~mm} \times 30 \mathrm{~mm}$, dan kotak $10 \mathrm{~mm} \times 10 \mathrm{~mm}$. Pemotongan dilakukan dengan mesin potong otomatis DAD3350. Setelah dipotong, sampel dibersihkan secara ultrasonik dalam aseton selama 10 menit untuk menghilangkan debu silikon yang berasal dari proses pemotongan dan partikel organik yang mungkin menempel pada permukaan substrat. Sampel kemudian dibilas dengan isopropanol, dihujani dengan air deionisasi, dan dikeringkan dengan hembusan N2. Semua sampel dipanaskan hingga suhu $150^{\circ} \mathrm{C}$ untuk memastikan pembuangan residu organik.

Tabel 1. Parameter sputtering Ta, Pt, Cr, dan Au.

\begin{tabular}{|l|c|c|c|c|}
\hline Target & $\mathrm{Ta}$ & $\mathrm{Pt}$ & $\mathrm{Cr}$ & $\mathrm{Au}$ \\
\hline $\begin{array}{l}\text { Diameter } \\
\text { target (inci) }\end{array}$ & 4 & 4 & 8 & 8 \\
\hline $\begin{array}{l}\text { Tekanan } \\
\text { sputtering } \\
\text { (mbar) }\end{array}$ & $4 \times 10^{-3}$ & $8 \times 10^{-3}$ & $4 \times 10^{-3}$ & $6 \times 10^{-3}$ \\
\hline $\begin{array}{l}\text { Laju aliran } \\
\text { udara } \\
\text { (sscm) }\end{array}$ & 30 & 25 & 25 & 25 \\
\hline $\begin{array}{l}\text { Tipe } \\
\text { sputtering }\end{array}$ & $\mathrm{RF}$ & $\mathrm{DC}$ & $\mathrm{DC}$ & $\mathrm{DC}$ \\
\hline Daya (W) & 200 & 100 & 200 & 200 \\
\hline $\begin{array}{l}\text { Laju } \\
\text { deposisi } \\
\text { (nm/s) }\end{array}$ & 4.95 & 8.71 & 0.55 & 1.10 \\
\hline
\end{tabular}

\section{B. Pengaturan Sputtering}

Proses sputtering dilakukan oleh sistem kluster magnetron Von-Ardenne CS 730 S, yang terdiri dari dua kamar sputtering dan satu kamar etching dengan total 9 posisi target. Sampel berbagai dimensi disusun pada substrate holder 6 inci untuk proses deposisi.

Konfigurasi kamar etching dimana deposisi AlN dilakukan dijelaskan sebagai berikut. Medan magnet dihasilkan oleh satu set magnet di atas target aluminium. Sistem pendingin air diterapkan pada target aluminium dan magnetron. Sebuah pompa turbomolekular Pfeiffer dioperasikan untuk menghasilkan ruang hampa udara yang tinggi dan didukung oleh forepump (pompa membran). Pfeiffer pressure gauge dan MKS Baratron pressure gauge digunakan masing-masing untuk memantau tekanan dasar dan tekanan sputtering. Tekanan selama sputtering dikendalikan dengan menggunakan throttle valve melalui sebuah pressure control unit (PCU). Laju aliran gas yang disuplai baik $\mathrm{N}_{2}$ atau Ar dikontrol oleh pengontrol aliran massa MKS dan disuplai ke kamar vakum selama proses deposisi.

\section{Parameter Sputtering}

Parameter sputtering dari deposisi semua thin film dan khususnya thin film dari AlN dirangkum dalam Tabel 2 dan Tabel 3. 
Tabel 2. Parameter sputtering untuk AlN.

\begin{tabular}{|l|c|}
\hline \multicolumn{1}{|c|}{ Parameter } & Besaran \\
\hline Diameter Target $(\mathrm{Al})$ & $8 \mathrm{inch}$ \\
\hline Jarak target-substrat & $8 \mathrm{~cm}$ \\
\hline Tekanan deposisi & $2 \times 10^{-3}$ \\
\hline Laju aliran $\mathrm{N}_{2}$ & $10 \mathrm{sscm}$ \\
\hline Daya pulsed DC & $1500 \mathrm{~W}$ \\
\hline Frekuensi pulsa & $250 \mathrm{kHz}$ \\
\hline Reverse time & $1.6 \mu \mathrm{m}$ \\
\hline Laju deposisi & $0.89 \mathrm{~nm} / \mathrm{s}$ \\
\hline
\end{tabular}

Tabel 3. Parameter sputtering untuk AlN.

\begin{tabular}{|l|c|}
\hline Parameter & Besaran \\
\hline Diameter Target (Al) & 8 inch \\
\hline Jarak target-substrat & $8 \mathrm{~cm}$ \\
\hline Tekanan deposisi & $2 \times 10^{-3}$ \\
\hline Laju aliran N2 & $10 \mathrm{sscm}$ \\
\hline Daya pulsed DC & $1500 \mathrm{~W}$ \\
\hline Frekuensi pulsa & $250 \mathrm{kHz}$ \\
\hline Reverse time & $1.6 \mu \mathrm{m}$ \\
\hline Laju deposisi & $0.89 \mathrm{~nm} / \mathrm{s}$ \\
\hline
\end{tabular}

D. Variasi Waktu Pra-etching dan Tebal AlN.

Parameter sputtering dari Ta, $\mathrm{Pt}, \mathrm{Cr}$, dan $\mathrm{Au}$ pada Tabel 2 dan AlN pada Tabel 3 dijaga konstan. Dua tumpukan yang dihasilkan dalam percobaan berikut ditunjukkan pada Gambar 8 .

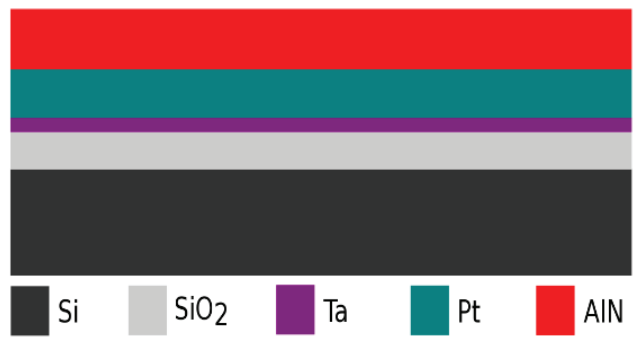

Gambar 8. Skematik thin film yang dideposisikan di atas substrat $\mathrm{Si} / \mathrm{SiO}_{2}$.

Untuk variasi waktu pra-etching, kurvatur substrat $\mathrm{Si}$ sebelum dideposisikan film diukur dengan profilometer. Proses pra-etching selama $30 \mathrm{~s}$ dan $60 \mathrm{~s}$ secara individual diterapkan pada substrat dan sebelum tahap deposisi film berikutnya. Setelah deposisi film Pt dan AlN, defleksi sampel diukur secara berurutan. Ketebalan nilai film hasil deposisi adalah $15 \mathrm{~nm}$ Ta, $0.15 \mathrm{~m}$ $\mathrm{Pt}$, dan $0.5 \mathrm{~m}$ AlN. Pengukuran XRD dilakukan untuk menentukan pengaruh waktu pra-etching pada kualitas pertumbuhan kristal film AlN.

Untuk variasi ketebalan film, AlN dideposisikan dengan masing-masing tebal, yaitu 0.5, 1.0, 1.5 , dan $2.0 \mu \mathrm{m}$ di atas $\mathrm{Pt}$, yang berfungsi sebagai seed layer dan elektroda bawah. Stylus scan dengan profilometer diterapkan secara berurutan pada sampel setelah deposisi film Pt dan AlN. Pengukuran XRD juga dilakukan. Sampel chip dengan tumpukan film Ta/Pt/AlN kemudian ditutup dengan $10 \mathrm{~nm}$ Cr dan $100 \mathrm{~nm}$ Au sebagai elektroda bagian atas terkait pengukuran $e_{31, f}$. Struktur elektroda atas difabrikasi oleh proses fotolitografi.

\section{E. Pengukuran Stress}

Stylus scan diterapkan untuk mengukur defleksi sampel. Jari-jari kelengkungan sampel diukur dengan pendekatan polinomial orde dua dengan sejumlah titik data defleksi sampel. Profil kurvatur dari sampel poligon disesuaikan dengan menggunakan Origin Lab. Adapun pengukuran residual stress rata-rata menggunakan program Matlab.

\section{F. Pengukuran $X R D$}

Sampel berbentuk kotak digunakan untuk investigasi mikrostruktural oleh XRD System 3000 PTS dari Seifert. Tegangan dan arus katoda yang diterapkan masing-masing adalah $40 \mathrm{kV}$ dan $40 \mathrm{~mA}$. $\theta-2 \theta$ scan dilakukan secara bertahap dengan variasi $2 \theta$ dari $30^{\circ}$ sampai dengan $90^{\circ}$. $\omega$ scan dilakukan di mana $2 \theta$ diatur tetap pada sudut dimana puncak Bragg dari AlN (0002) ditunjukkan. $\omega$ scan bervariasi dari $12^{\circ}$ sampai dengan $28^{\circ}$. Tingkat kenaikan sudut dan waktu hitung untuk $\theta-2 \theta$ scan dan $\omega$ scan masing-masing adalah $0.05^{\circ}$ dan $1 \mathrm{~s}$. FWHM dari rocking curve diukur dengan menerapkan Gaussian fit dengan sejumlah titik data intensitas sinar-x. 


\section{G. Litography}

Proses litography dilakukan untuk strukturisasi elektroda atas dari sampel yang digunakan pada pengukuran $e_{31, f}$ Hexamethyldisilazane (HMDS) diaplikasikan pada sampel untuk meningkatkan daya rekat dari resist ke film. $0.5 \mathrm{ml}$ positive resist (AZ6332) diaplikasikan pada sampel dengan menggunakan spin coater. Setelah aplikasi resist, sampel dipanggang di atas hot plate dengan suhu $110^{\circ} \mathrm{C}$ selama $50 \mathrm{~s}$ dan kemudian didinginkan di suhu lingkungan. Mode hard contact digunakan selama paparan UV untuk mentransfer struktur dari mask ke resist. Selanjutnya sampel dikembangkan dalam AZ726MIF selama 45 s. Setelah dibilas dengan air deionisasi dan dikeringkan dengan N2, sampel tersebut dikeringkan pada suhu $125^{\circ} \mathrm{C}$ selama 50 s. Etching dilakukan pada lapisan $\mathrm{Cr}$ dan Au dengan masing-masing etchant. Resist yang tersisa pada sampel dilucuti dengan rendaman aseton-ultrasonik, kemudian dibilas dengan isopropanol dan air deionisasi. Sampel kemudian dipotong menjadi bentuk balok, seperti yang ditunjukkan pada Gambar 9.

\section{H. Metode 4-point Bending}

Koefisien piezoelektrik transversal efektif $e_{31, f}$ diperoleh dengan menggunakan sistem aix-ACCT 4-point Bending (aix4PB). Prinsip pengukuran ditunjukkan pada Gambar 9. Kapasitansi masing-masing sampel diukur dengan multimeter untuk perhitungan permitivitas relatif.

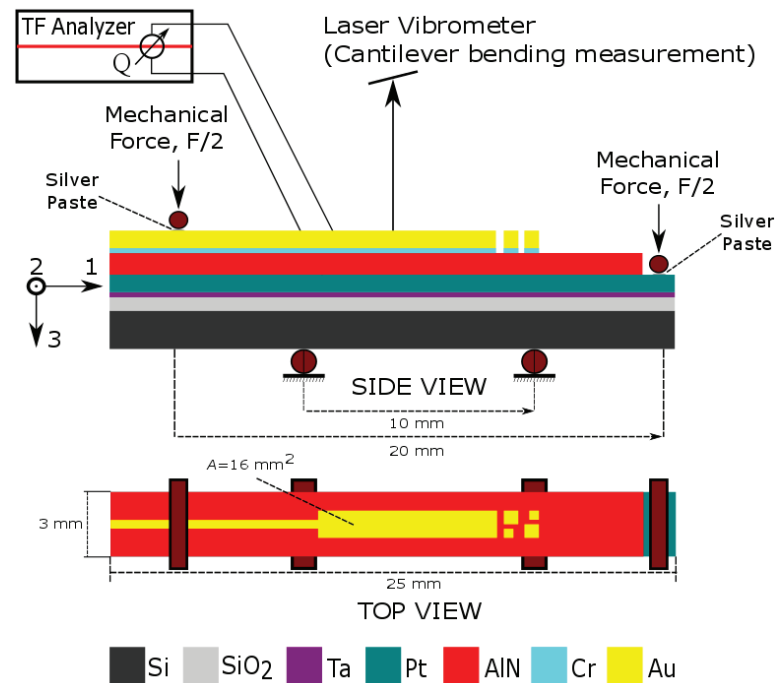

Gambar 9. Skematik struktur sampel dan pengaturan pengukuran 4-point bending.

\section{HASIL PENELITIAN DAN PEMBAHASAN}

\section{A. Pengaruh Variasi Waktu Pra-etching}

Pengaruh variasi waktu pra-etching (PE) terhadap parameter residual stress dan FWHM yang diukur dapat dirangkum pada Tabel 4. Variasi waktu pra-etching, $30 \mathrm{~s}$ dan $60 \mathrm{~s}$, tidak mempengaruhi residual stress dari film AlN secara signifikan dan FWHM dari puncak (0002). Meskipun demikian, peningkatan kecil pada nilai residual stress diamati dengan meningkatkan waktu praetching. Dalam waktu pra-etching yang lebih lama, permukaan lapisan film Pt dan substrat dibombardir oleh ion argon yang energetik lebih lama. Bombardir ion argon memunculkan sejumlah vacancy clusters atau voids pada permukaan thin film yang dideposit sebelumnya. Film AlN kemudian menunjukkan kecenderungan untuk berkontraksi dengan peningkatan jumlah voids.

Tabel 4. Hasil pengukuran residual stress AlN dan FWHM pada sampel yang memperoleh variasi waktu pra-etching.

\begin{tabular}{|l|c|c|c|}
\hline Layer & $\begin{array}{c}\text { Waktu PE } \\
(\mathbf{s})\end{array}$ & $\begin{array}{c}\boldsymbol{\sigma}_{\boldsymbol{f}} \\
(\mathbf{G P a})\end{array}$ & $\begin{array}{c}\text { FWHM } \\
\left({ }^{\circ}\right)\end{array}$ \\
\hline $\mathrm{AlN}$ & 30 & $0.65 \pm 0.05$ & 1.83 \\
\hline $\mathrm{AlN}$ & 60 & $0.70 \pm 0.04$ & 1.77 \\
\hline
\end{tabular}

Rocking curve FWHM yang lebih sempit pada waktu pra-etching $60 \mathrm{~s}$ dikaitkan dengan permukaan Pt yang lebih halus dengan bombardir ion yang lebih lama. Dengan meningkatnya waktu pra-etching, sejumlah kontaminan yang terikat lemah pada permukaan substrat dan film semakin dibersihkan. Hal ini menghasilkan permukaan yang lebih halus untuk menghindari shadowing dan meningkatkan mobilitas atom pada permukaan substrat dan film sehingga mendukung pertumbuhan kristal berbentuk kolom. Oleh karena itu kristalinitas film AlN lebih baik pada waktu pra-etching $60 \mathrm{~s}$.

\section{B. Pengaruh Variasi Ketebalan Film AlN}

Pengaruh variasi ketebalan film AlN terhadap parameter residual stress, FWHM, dan koefisien piezoelektrik transversal efektif $\left(e_{31, f}\right)$ yang diukur dapat dirangkum pada Tabel 5. Dengan 
meningkatnya ketebalan film, residual stress AlN cenderung untuk menurun (lihat Gambar

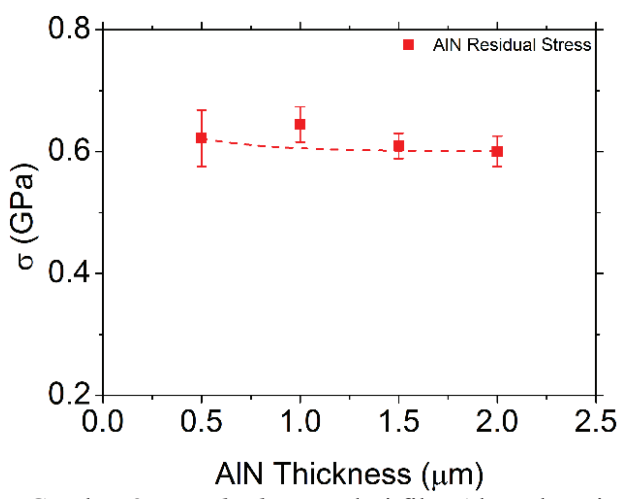

10) sebagai akibat dari penggabungan atom ke dalam grain boundaries dan proses pertumbuhan grains. Ketika ketebalan film AlN terus meningkat, sejumlah molekul dan adatom mulai berdifusi ke dalam grain boundaries. Ketika difusi berlanjut, densitas grain boundaries menurun, ukuran grains meningkat, dan gaya tarik menarik antara columnar grains yang berdekatan menjadi berkurang. Dengan demikian columnar grains yang padat tumbuh secara preferensial dan tensile stress berkurang.

Tabel 5. Hasil pengukuran residual stress AlN, FWHM, dan e31,fpada sampel yang memperoleh variasi ketebalan film AlN.

\begin{tabular}{|c|c|c|c|}
\hline $\begin{array}{c}\text { Tebal AIN } \\
(\boldsymbol{\mu m})\end{array}$ & $\begin{array}{c}\boldsymbol{\sigma}_{\boldsymbol{f}} \\
(\mathbf{G P a})\end{array}$ & $\begin{array}{c}\text { FWHM } \\
\left.\mathbf{(}^{\circ}\right)\end{array}$ & $\begin{array}{c}\boldsymbol{e}_{31, f} \\
\left(\mathbf{C} / \mathbf{m}^{2}\right)\end{array}$ \\
\hline 0.5 & $0.62 \pm 0.05$ & 1.66 & -1.34 \\
\hline 1.0 & $0.64 \pm 0.03$ & 1.42 & -1.47 \\
\hline 1.5 & $0.61 \pm 0.02$ & 1.55 & -1.38 \\
\hline 2.0 & $0.60 \pm 0.03$ & 1.29 & -1.40 \\
\hline
\end{tabular}

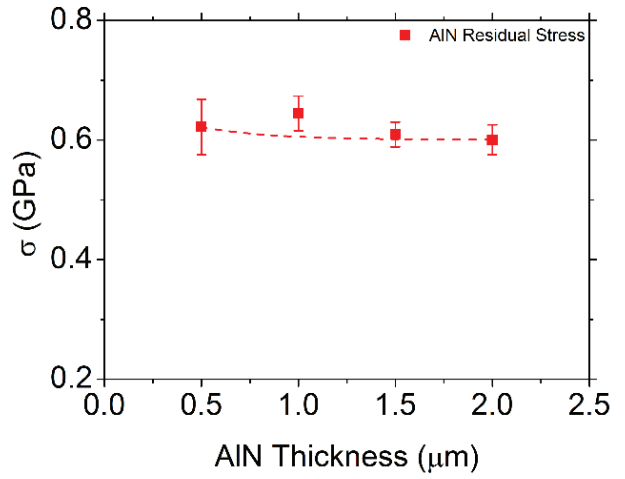

Gambar 10. Residual stress dari film AlN sebagai fungsi tebal film AlN. $\theta-2 \theta$ scan menunjukkan semua film AlN tumbuh dengan kristal berbentuk kolom dan memiliki orientasi pada sumbu-c. Peningkatan intensitas puncak pada Gambar 11 dijelaskan oleh

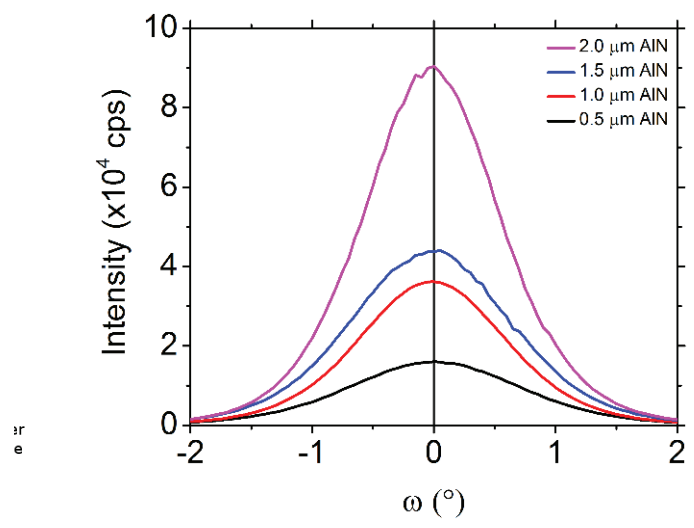

peningkatan jumlah dan ukuran grains dengan orientasi preferensial, yaitu kristal AlN dengan orientasi (0002). Dengan meningkatnya ketebalan film AlN, grains dengan orientasi (0002) tumbuh lebih besar dan mengkonsumsi grains lain dengan orientasi yang berbeda. Grains dengan orientasi (0002) kemudian mendominasi pada film AlN. Oleh karena itu, hasil difraksi x-ray lebih didominasi oleh interaksi sinar-x dengan bidang (0002).

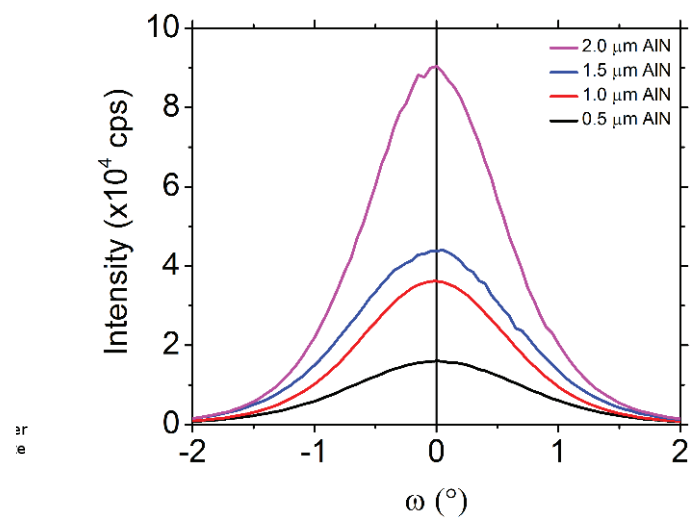

Gambar 11. Hasil rocking curves dari AlN (0002).

FWHM dari rocking curve semakin kecil dengan penambahan ketebalan film AlN (lihat Gambar 12) yang diakibatkan oleh peningkatan jumlah dan ukuran kristal AlN dengan orientasi (0002). Penyempitan lebar FWHM juga dapat dijelaskan oleh penurunan distribusi 
inhomogeneous strain dan peningkatan coherence length pada ketebalan film AlN yang lebih tinggi. Pada ketebalan film $1.5 \mu m$, penyimpangan FWHM diamati tetapi nilai ini masih dapat diterima. Hal ini dapat diduga akibat kesalahan pengukuran XRD, misalnya, pemasangan sampel yang tidak presisi pada goniometer. Kemungkinan lain adalah implantasi ion selama deposisi film AlN yang mengakibatkan inhomogeneous strain pada permukaan film AlN. Lattice di lapisan atas mengembang sedemikian rupa sehingga jarak interplanar menjadi lebih besar daripada lapisan di bawah yang menyebabkan perluasan FWHM.

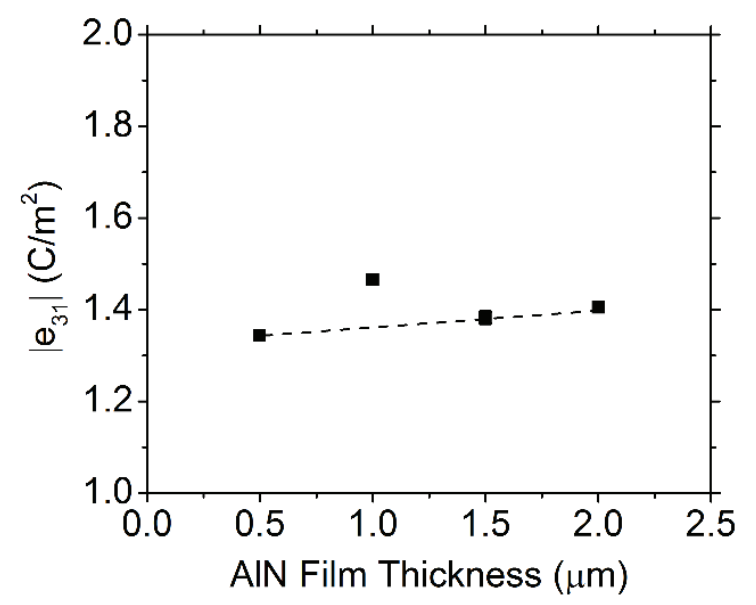

Gambar 12. FWHM sebagai fungsi dari ketebalan film AlN.

Peningkatan kualitas kristal pada ketebalan film AlN yang lebih tinggi berkorelasi dengan peningkatan koefisien piezoelektrik transversal efektif. Dengan struktur kristal kolumnar yang lebih baik, polarisasi sepanjang sumbu-c cenderung dipertahankan dalam film dengan residual stress yang rendah. Dalam studi ini, $\left|e_{31, f}\right|$ menjadi maksimum karena residual stress dari film AlN yang minimum. Deviasi kecil diamati pada ketebalan film $1 \mu \mathrm{m}$.

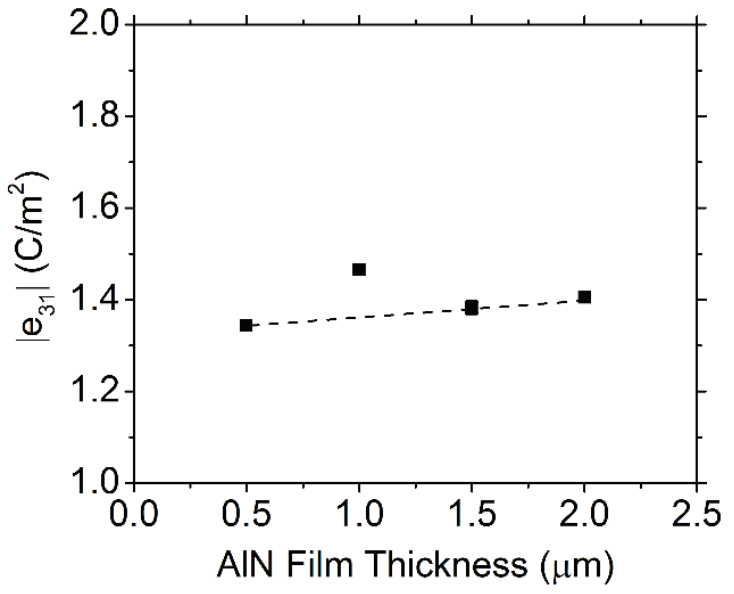

Gambar 13. $\left|e_{31, f}\right|$ dari AlN sebagai fungsi dari
ketebalan film AlN.

\section{KESIMPULAN}

Optimalisasi stress dari thin film aluminium nitrida telah dilakukan dengan variasi parameter sputtering tanpa menurunkan sifat piezoelektrik dari thin film AlN. Parameter sputtering yang divariasikan meliputi waktu pra-etching dan ketebalan film AlN. Pengaruh parameter tersebut terhadap residual stress, mikrostruktural, dan respon piezoelektrik telah disajikan.

Pengaruh waktu pra-etching pada residual stress dan mikrostruktural AlN tidak signifikan. Tensile stress tetap diamati dalam film AlN. Pada waktu pra-etching yang lebih lama, penurunan kecil dari FWHM telah dihasilkan. Hal ini disebabkan oleh permukaan film yang lebih halus akibat dari bombardir ion yang menghasilkan desorpsi kontaminan yang terikat lemah pada permukaan film.

Tensile stress yang lebih rendah telah diamati pada film AlN dengan ketebalan yang lebih tinggi. Mikrostruktural AlN yang berbentuk kolom tumbuh lebih baik pada film AlN dengan ketebalan yang tinggi. Hal ini juga berdampak pada peningkatan nilai $e_{31, f .}$ Sebuah korelasi antara 
residual stress yang rendah, kualitas pertumbuhan kristal berbentuk kolom yang ditingkatkan, dan respon piezoelektrik yang lebih tinggi telah disajikan dari penambahan ketebalan film AlN.

\section{DAFTAR PUSTAKA}

Carter, G. 1994. "Peening in Ion-Assisted ThinFilm Deposition: A Generalized Model." Journal of Physics D: Applied Physics 27(5):1046-55.

Dubois, Marc-Alexandre and Paul Muralt. 2001. "Stress and Piezoelectric Properties of Aluminum Nitride Thin Films Deposited onto Metal Electrodes by Pulsed Direct Current Reactive Sputtering." Journal of Applied Physics 89(11):6389-95.

Eason, R. 2007. Pulsed Laser Deposition of Thin Films: Applications-Led Growth of Functional Materials. Wiley.

Gould, R. O. and W. Borchardt-Ott. 2011. Crystallography: An Introduction. Springer Berlin Heidelberg.

Hummel, R. E. 2012. Electronic Properties of Materials. Springer Berlin Heidelberg.

Jahns, Robert, S. Zabel, Stephan Marauska, B. Gojdka, B. Wagner, R. Knoechel, R. Adelung, and Franz Faupel. 2014. "Microelectromechanical Magnetic Field Sensor Based on $\Delta$ E Effect." Applied Physics Letters 105:52414.

Kittel, C. 2004. Introduction to Solid State Physics. Wiley.

Madou, M. J. 2018. Fundamentals of Microfabrication: The Science of Miniaturization, Second Edition. CRC Press.

Martin, F., Paul Muralt, Marc-Alexandre Dubois, and Aurélie Pezous. 2004. Thickness Dependence of the Properties of Highly C-Axis Textured AlN Thin Films. Vol. 22.

Martinez Guerrero, Reynaldo and Jorge roberto Vargas-garcia. 2000. "Preparation of Aluminum Nitride Thin Films by CVD." Materials and Manufacturing Processes MATER MANUF PROCESS 15:259-67.

Ohring, M. 2001. Materials Science of Thin Films. Elsevier Science.
Sardela, M. 2014. Practical Materials Characterization. Springer New York.

Smith, D. L. 1995. Thin-Film Deposition: Principles and Practice. McGraw-Hill Education.

Uchino, K. 2010. Advanced Piezoelectric Materials: Science and Technology. Elsevier Science. 